\title{
Macrophage Activation Syndrome Presented in a Case of Neonatal Lupus
}

\author{
Chang Min Kang, MD, Jinwha Choi, MD, PhD, and JungHwa Lee, MD, PhD \\ Department of Pediatrics, Korea University Guro Hospital, Korea University College of Medicine, Seoul, Korea
}

\section{ABSTRACT}

Macrophage activation syndrome (MAS) is a potentially life-threatening complication in many autoimmune diseases. Early recognition and intervention are essential for a favorable outcome. Neonatal lupus, an acquired autoimmune disease in neonates caused by the transplacental passage of maternal autoantibodies, is rare and usually self-limited. Herein, we report a case of MAS in a patient with neonatal lupus, which improved with intravenous immunoglobulin.

Key Words: Macrophage activation syndrome; Neonatal lupus; Immunoglobulins, intravenous

\section{서론}

신생아 루푸스는 모체의 자가 면역 항체가 태반을 통과하여 전달되면서 태아와 신생아에서 다양한 기관을 침범하는 루푸스의 증상을 보이는 질환으로, 모체의 항체가 소실되는 생후 6개월 경이 되면 선천성 완전 심장 전도 이상을 제외한 대부분의 증상은 호전된다 ${ }^{11}$. 루푸스와 같은 자 가면역질환은 감염과 더불어 대식세포 활성 증후군을 유발하는 주요 요인인데, 대식세포 활성 증후군에서 $\mathrm{T}$ 림프구와 대식세포는 비정상적으로 과도하게 활성화되고 혈구 탐식과 과염증상 태가 전신 기관의 기능 장애를 초래하여 높은 치사율을 보이게 된다 ${ }^{2)}$.

저자들은 무증상 자가항체 양성 산모에서 출생하여 신생아 루푸스로 진단된 환아에서 발생한 대식세포 활성 증후군 1례를 경험하여 보고하는 바이다.

\section{증례}

환아는 출산력 1-0-0-1의 경산부로부터 제왕절개로 타 병원에서 출생하였고 출생 당시 발진 있었으나 호전 경과 보이던 중 생후 30 일에 눈 주변 및 미간 부위의 수포성 병변과 반흔 소견 등 악화되어 본원에 입원하였다. 출생 시 재태기간 38 주 2 일, 출생 체중 $2,670 \mathrm{~g}$ 으로서 이상 소견 없 었고 환아의 모 및 가족력에서도 병력이나 특이사항은 없었다. 얼굴과 몸통 및 사지에 다수의 가피가 동반된 홍반성 고리 모양 반점이 관찰된 것 이외에 활력증후 및 진찰 소견에서 특이점은
Received: 28 June 2021

Revised: 10 August 2021

Accepted: 10 August 2021

Correspondence to: JungHwa Lee, $\mathrm{MD}, \mathrm{PhD}$

Department of Pediatrics, Korea University Guro Hospital, Korea University College of Medicine, 148 Gurodong-ro, Guro-gu, Seoul 08308, Korea

Tel: +82-2-2626-1227

Fax: +82-2-2626-1249

E-mail: leejmd@chol.com

Copyright(c)

By Korean Society of Neonatology.

This is an Open-Access article distributed under the terms of the Creative Commons At tribution Non-Commercial License (http:// creativecommons.org/licenses/by-nc/4.0), which permits unrestricted non-commercial use, distribution, and reproduction in any medium, provided the original work is properly cited. 
없었다. 혈액 검사상 혈소판 감소 $(79,000 / \mu \mathrm{L})$ 와 간효소 증가(아스 파르테이트아미노전달효소/알라닌아미노전달효소, 175/131 IU/L) 소견 보이며 항SSB 항체 음성이나 항핵항체 양성(1:80, speckled pattern), 항SSA 항체 $(>250 \mathrm{U} / \mathrm{mL})$ 와 항dsDNA 항체 $(10.3 \mathrm{IU} / \mathrm{mL})$ 양성 소견을 보여 신생아 루푸스 진단하에 심전도 및 심장초음파, 뇌 초음파 및 자기공명검사를 시행하였으며 심방중격결손 $(4 \mathrm{~mm})$ 이외의 이상 소견은 없었다. 환아의 모는 결체조직 질환을 의심 할 수 있는 증상이 전혀 없는 상태로 검사상 항핵항체 양성(1:640, speckled pattern), 항SSA 항체 $(>240 \mathrm{U} / \mathrm{mL})$, 항Sm 항체 $(58 \mathrm{U} / \mathrm{mL})$, 항RNP 항체 $(295 \mathrm{U} / \mathrm{mL})$ 양성 소견을 보였다. 환아는 이후 피부 소 견은 지속되고 있으나 호전 추세이고, 혈소판 수 $(136,000 / \mu \mathrm{L})$ 및 간 효소 수치(77/63 IU/L)가 회복되는 경과를 보여 생후 37일째 퇴원 하였다.

퇴원 후 생후 44 일째부터 환아는 발진이 악화되면서 38도 이상의 열과 구토를 주소로 45 일째 재입원하였다. 환아는 처져 보였으며 혈액 검사상 혈소판 $(103,000 / \mu \mathrm{L})$, 간효소(아스파르테이트아미노전 달효소/알라닌아미노전달효소, 214/111 IU/L), 젖산탈수효소(918 $\mathrm{IU} / \mathrm{L}), \mathrm{C}$-반응 단백 $(11.8 \mathrm{mg} / \mathrm{L}$, 정상 $<5 \mathrm{mg} / \mathrm{L})$, 적혈구침강속도 $(8$ $\mathrm{mm} / \mathrm{hr}$ )의 소견을 보였다. 그 외 뇌척수액 및 혈액 응고 검사, 소변 및 대변 검사, 호흡기 바이러스 검사상 이상 소견은 없었으며 복부 초음파 검사에서는 비장이 $7 \mathrm{~cm}$ 로 경증의 비대 소견을 보였다. 패 혈증을 의심하여 경험적 항생제 투여하며 경과 관찰하던 중 구토는 호전되었으나 열은 지속되고 혈소판은 더욱 감소하고 간효소와 젖 산분해효소, C-반응 단백은 더욱 증가하였다. 입원 5일(생후 49일) 째 환아가 수면 중 보채는 증상이 심해져서 시행한 뇌파에서 경련을
시사하는 소견은 없었고 신경학적 진찰에서도 특이 소견은 없었다. 혈액 및 소변, 뇌척수액 배양 검사상 음성 확인 후 시행한 검사상 중 성구 $(305 / \mu \mathrm{L})$, 혈소판 $(37,000 / \mu \mathrm{L})$, 간효소(아스파르테이트아미노전 달효소/알라닌아미노전달효소, 357/260 IU/L), 젖산탈수효소(1,202 $\mathrm{IU} / \mathrm{L}), \mathrm{C}$-반응 단백 $(9.8 \mathrm{mg} / \mathrm{L})$, 페리틴 $(2,629 \mathrm{ng} / \mathrm{mL})$, 중성지방 $(200$ $\mathrm{mg} / \mathrm{dL})$, 섬유소원 $(246 \mathrm{mg} / \mathrm{dL})$, 섬유소분해산물 $(11.27 \mu \mathrm{g} / \mathrm{mL}), \mathrm{D}-$ 이합체 $(3.49 \mu \mathrm{g} / \mathrm{mL})$ 의 소견을 보였다. 이후 채혈로 인한 짧은 기간 내 적혈구 손실 $(8.6 \mathrm{~g} / \mathrm{dL})$ 을 보충하기 위해 농축 적혈구를 수혈하였 고 또한 혈소판 감소 및 전신 염증 소견에 대해 정맥용 면역글로불 린 $(1 \mathrm{~g} / \mathrm{kg} / \mathrm{day})$ 을 2일간 투여하였다. 입원 7일(생후 51일)째부터 열 은 38도 이하로 유지되면서 중성구 수를 제외한 모든 혈액 수치들 이 호전 양상을 보여 경과 관찰하던 중 미열과 중성구 수 감소현상 이 지속되어 입원 9일(생후 53일)째 과립구 증식인자(granulocytecolony stimulating factor)를 이틀간 투여하였다. 입원 11일(생후 55 일)째 체온은 37 도 이하로 유지되었고 보채는 증상과 발진이 현저히 호전되었으며 중성구와 혈소판 수도 호전되었다. 환아는 하루 더 경 과 관찰하였으며 안정적인 상태로 퇴원하였고 퇴원 후에도 5 개월째 이상 증상 없이 정상적인 성장과 발달을 유지하고 있다. 환아의 임 상경과 및 검사 소견은 그림 1에 요약하였다(Figure 1).

\section{고찰}

신생아 루푸스와 주로 연관되는 자가항체는 항SSA 항체와 항SSB 항체로서, 자가항체를 가진 산모에서 태어난 신생아의 약 1\%-2\%

\begin{tabular}{|c|c|c|c|c|c|c|c|c|c|c|c|c|}
\hline \multirow[b]{2}{*}{ Age (d) } & \multicolumn{2}{|c|}{ 1st admission } & \multirow{2}{*}{$\begin{array}{c}\text { Home } \\
\# 45\end{array}$} & \multicolumn{6}{|c|}{ 2nd admission } & \multicolumn{3}{|c|}{ Home } \\
\hline & $\# 31$ & $\# 38$ & & $\# 46$ & $\# 48$ & \#50 & $\# 52$ & $\# 54$ & \#56 & $\# 67$ & $\# 86$ & \#177 \\
\hline Highest BT $\left({ }^{\circ} \mathrm{C}\right)$ & 36.7 & 37 & $>38$ & 38.4 & 38.2 & 37.9 & 37.7 & 37.6 & 37 & 37 & 37.3 & 36.3 \\
\hline Rash & +++ & ++ & H+ & +r+ & +H & +H & ++ & ++ & ++ & + & \pm & - \\
\hline \multirow[t]{3}{*}{ Irritability } & & & + & + & + & ++ & ++ & + & \pm & \pm & - & - \\
\hline & & & & \multicolumn{3}{|c|}{ Ampicillin + Gentamycin } & \multicolumn{3}{|c|}{ Ampicillin/Sulbactam } & & & \\
\hline & & & & & & $\downarrow$ & $\begin{array}{l}\text { pRBC } \\
\text { IVIG }\end{array}$ & $\downarrow$ & G-CSF & & & \\
\hline $\mathbf{H b}(\mathrm{g} / \mathbf{d L})$ & 11.2 & 8.8 & & 9.7 & 8.8 & 8.6 & 10.9 & 10.5 & 9.4 & 8.7 & 10 & 12.2 \\
\hline $\operatorname{ANC}(/ \mathbf{m L})$ & 1701 & 1296 & & 2205 & 1191 & 305 & 183 & 217 & 8345 & 1965 & 1254 & 2507 \\
\hline Platelet $\left(10^{3} / \mathrm{mL}\right)$ & 79 & 136 & & 103 & 73 & 37 & 52 & 81 & 120 & 180 & 188 & 381 \\
\hline $\operatorname{CRP}(\mathrm{mg} / \mathrm{L})$ & 2.92 & 0.97 & & 11.8 & 23.9 & 9.8 & 5.2 & 2.44 & & & & \\
\hline $\mathbf{A S T}(\mathbf{U} / \mathbf{L})$ & 175 & 77 & & 214 & 408 & 357 & 290 & 150 & & 197 & 112 & 74 \\
\hline $\operatorname{ALT}(\mathbf{U} / \mathbf{L})$ & 131 & 63 & & 111 & 227 & 260 & 214 & 149 & & 176 & 156 & 84 \\
\hline LDH (U/L) & & & & 918 & 1462 & 1202 & 887 & 721 & & 675 & & \\
\hline Ferritin $(\mathbf{n g} / \mathbf{m L})$ & & & & & & 2629 & 2371 & & & 539 & & \\
\hline TG (mg/dL) & & & & & & 200 & 215 & 241 & & 164 & & \\
\hline Fibrinogen (mg/dL) & & & & & & 246 & 281 & & & & & \\
\hline
\end{tabular}

Figure 1. Changes in clinical course and laboratory findings in our case. Abbreviations: BT, body temperature; pRBC, packed red blood cells; IVIG, intravenous immunoglobulin; G-CSF, granulocyte-colony stimulating factor; Hb, hemoglobin; ANC, Absolute neutrophil count; CRP, C-reactive protein; AST, aspartate transaminase; ALT, alanine aminotransferase; LDH, lactate dehydrogenase; TG, triglyceride. 
에서 루푸스가 발생한다 ${ }^{1,3)}$. 신생아 루푸스의 증상 중 특히 선천성 심장 전도 이상은 환아의 약 15\%-30\%에서 태생기 18주에서 24주 사이에 발생하고 이는 선천 심장 전도 이상의 주된 원인으로 완전 형의 경우 심박조율기의 삽입이 필요하다 ${ }^{4)}$. 비가역적인 심장 합병 증의 예방으로 fluorinated steroid bethametasone 및 intravenous immunoglobulin이 제안 되고 있으며 이를 위해서 빠른 산전 진단이 필수이나 본 증례에서와 같이 산모가 자가면역질환의 병력이나 증 상이 없는 경우가 신생아 루푸스 산모의 $40 \%-60 \%$ 에 이르고 ${ }^{1)}$ 이 경 우 출생 후 나타나는 증상에 의해 진단될 수밖에 없으므로 심장 합 병증을 예방할 수 있는 기회를 놓치게 된다. 따라서 선천 심장 전도 이상의 예방을 위해 산전 진단 검사에 항핵항체를 포함시키는 것에 대한 고려가 필요하다.

자가면역질환 중 루푸스는 전신형 소아 특발성 관절염 다음으로 대식세포 활성 증후군의 발생과 연관되며 약 0.9\%-4.6\%의 유병률 을 보인다 ${ }^{5)}$. 대식세포 활성 증후군은 높은 치사율 때문에 빠른 진단 이 예후를 결정하는 가장 중요한 요소이나 임상 증상과 검사 소견의 특이성이 낮기 때문에 진단이 늦어지는 경우가 많다. 자가면역질환 이나 자가염증성 질환, 감염 등 대식세포활성 증후군과 연관되는 기 저질환 자체의 재발이나 악화 소견은 대식세포활성 증후군의 임상 증상과 검사 소견과 매우 유사하다. 또한 대식세포 활성 증후군의 기저질환에 따라 검사 소견의 양상이 다양하므로 일률적인 진단적 검사치를 적용하기는 매우 어렵다 ${ }^{6-9)}$. 이에 기저질환별 대식세포 활 성 증후군의 진단기준은 다를 수밖에 없는데 2009년 발표된 루푸스 에서의 대식세포 활성 증후군의 진단 기준에 의하면 임상 기준으로 발열(>38도), 간비대(늑골연 $>3 \mathrm{~cm})$, 비장비대(늑골연 $>3 \mathrm{~cm})$, 출 혈 소견(자반, 멍, 점막 출혈), 중추신경계 이상 소견(보챔, 지남력 장애, 무기력, 두통, 경련, 혼수) 중 1 개 이상과, 검사 기준으로 2계통 이상의 혈구세포 감소(백혈구 $<4,000 / \mu \mathrm{L}$, 혈색소 $<9.0 \mathrm{~g} / \mathrm{dL}$, 혈소판 $<150,000 / \mu \mathrm{L})$, 아스파르테이트아미노전달효소 증가 $(>40 \mathrm{U} / \mathrm{L})$, 젓 산탈수효소 증가 $(>567 \mathrm{U} / \mathrm{L})$, 섬유소원 감소( $<150 \mathrm{mg} / \mathrm{dL})$, 중성지 방 증가 $(>178 \mathrm{mg} / \mathrm{dL})$, 페리틴 증가 $(>500 \mathrm{ng} / \mathrm{ml})$ 중 2 개 이상을 보 이면 진단할 수 있다고 하였다 ${ }^{10)}$. 하지만 이러한 진단기준이 추출된 대상 집단의 평균 연령이 12 세이므로 이 기준이 신생아 루푸스에서 도 그대로 적용될 수 있을지는 아직 확인되지 않았다.

대식세포 활성 증후군의 치료는 혈구탐식성 림프조직구증에 비 해 정립된 것은 아니지만 대용량 스테로이드가 일차적으로 사용되 고 있다. 지금까지 보고된 신생아 루푸스와 연관된 대식세포 활성 증 후군 증례 5례를 살펴보면 정맥용 hydrocortisone이나 prednisolone 이 사용된 경우가 4례, 정맥용 면역글로불린과 HLH-2004 protocol 이 사용된 경우가 1 례 있었다 ${ }^{3,11-13)}$. 본 증례에서는 환아의 진찰 소견 과 검사 소견을 주의 깊게 관찰하면서 입원 5일째 스테로이드에 앞 서 정맥용 면역글로불린을 이틀간 먼저 투여하였고 이후 전신 염증 소견의 진행은 멈추고 호전되는 양상을 보이기 시작하여 이전 보고
된 증례와는 다르게 더 이상의 면역억제 치료가 필요하지 않았다. 신생아 루푸스에서 진행된 대식세포 활성 증후군의 진단 기준이 확 립되지 않은 상태에서 더 이상의 강력한 면역억제 치료 없이 호전 된 점은 본 증례가 완전한 대식세포 증후군의 전 단계였을 가능성 도 있다.

본 증례를 통해 대식세포 활성 증후군의 진단에 있어 가장 중요한 것은 자가면역질환이나 자가염증성질환, 감염이 호전되지 않을 때 대식세포 활성 증후군의 가능성을 항상 염두에 두어야 한다는 것이 고, 기저 검사 소견에서의 변동 양상을 주의 깊게 관찰하다가 늦지 않게 치료하여 질병의 진행으로 인한 합병증과 후유증을 예방하여 야 한다는 점을 다시 한번 강조하고자 한다.

\section{ARTICLE INFORMATION}

\section{Ethical statement}

This study was approved by the Korea University Medical Center Guro Hospital (IRB No.2021GR0293). Informed consent was waived by the board.

\section{Conflicts of interest}

No potential conflict of interest relevant to this article was reported.

\section{Author contributions}

Conception or design: C.M.K., J.C., J.H.L.

Acquisition, analysis, or interpretation of data: C.M.K., J.C., J.H.L.

Drafting the work or revising: C.M.K., J.H.L.

Final approval of the manuscript: J.H.L.

\section{ORCID}

Chang Min Kang https://orcid.org/0000-0001-5670-3635

JungHwa Lee https://orcid.org/0000-0002-6592-3653

\section{Acknowledgments}

None

\section{REFERENCES}

1. Hon KL, Leung AK. Neonatal lupus erythematosus. Autoimmune Dis 2012;2012:301274.

2. Alongi A, Naddei R, De Miglio L, Natoli V, Ravelli A. Macrophage 
activation syndrome in pediatrics. Pediatr Allergy Immunol 2020;31 Suppl 24:13-5.

3. Heijstek V, Habib M, van der Palen R, van Doorn R, Muller PH. Macrophage activation syndrome in a newborn: report of a case associated with neonatal lupus erythematosus and a summary of the literature. Pediatr Rheumatol Online J 2021;19:13.

4. Izmirly PM, Saxena A, Kim MY, Wang D, Sahl SK, Llanos C, et al. Maternal and fetal factors associated with mortality and morbidity in a multi-racial/ethnic registry of anti-SSA/Roassociated cardiac neonatal lupus. Circulation 2011;124:1927-35.

5. Fukaya S, Yasuda S, Hashimoto T, Oku K, Kataoka H, Horita T, et al. Clinical features of haemophagocytic syndrome in patients with systemic autoimmune diseases: analysis of 30 cases. Rheumatology (Oxford) 2008;47:1686-9

6. Ahn SS, Yoo BW, Jung SM, Lee SW, Park YB, Song JJ. Application of the 2016 EULAR/ACR/PRINTO classification criteria for macrophage activation syndrome in patients with adult-onset still disease. J Rheumatol 2017;44:996-1003.

7. Borgia RE, Gerstein M, Levy DM, Silverman ED, Hiraki LT. Features, treatment, and outcomes of macrophage activation syndrome in childhood-onset systemic lupus erythematosus. Arthritis Rheumatol 2018;70:616-24.

8. Han SB, Lee SY, Jeong DC, Kang JH. Should 2016 criteria for macrophage activation syndrome be applied in children with
Kawasaki disease, as well as with systemic-onset juvenile idiopathic arthritis? Ann Rheum Dis 2016;75:e44.

9. Ravelli A, Minoia F, Davi S, Horne A, Bovis F, Pistorio A, et al. 2016 Classification criteria for macrophage activation syndrome complicating systemic juvenile idiopathic arthritis: a European League Against Rheumatism/American College of Rheumatology/Paediatric Rheumatology International Trials Organisation Collaborative Initiative. Arthritis Rheumatol 2016; 68:566-76.

10. Parodi A, Davi S, Pringe AB, Pistorio A, Ruperto N, MagniManzoni S, et al. Macrophage activation syndrome in juvenile systemic lupus erythematosus: a multinational multicenter study of thirty-eight patients. Arthritis Rheum 2009;60:3388-99.

11. Suzuki Y, Takahashi N, Yada Y, Koike Y, Matano M, Nishimura H, et al. Hemophagocytic lymphohistiocytosis in a newborn infant born to a mother with Sjögren syndrome antibodies. J Perinatol 2013;33:569-71.

12. Shimozawa H, Kono Y, Matano M, Suzuki Y, Koike Y, Yada $\mathrm{Y}$, et al. Cytokine profile in two siblings with neonatal lupus erythematosus. Pediatr Int 2015;57:1211-4.

13. ParkJH, Kim SH, Kim HJ, Lee SJ, Jeong DC, Kim SY. Macrophage activation syndrome in a newborn infant born to a mother with autoimmune disease. J Perinatol 2015;35:158-60. 